\title{
Comparison of Two Semen Extenders in Terms of In Vitro Development of Bovine Embryos Following IVF
}

\author{
By P. Lonergan ${ }^{1}$, E. Kommisrud ${ }^{2}$ and A. L. Hafne ${ }^{1}$ \\ ${ }^{1}$ Department of Reproduction and Forensic Medicine, Norwegian College of Veterinary Medicine, Oslo, and \\ ${ }^{2}$ Norwegian Red Cattle Association, Hamar, Norway.
}

\begin{abstract}
Lonergan, P., E. Kommisrud and A.L. Hafne: Comparison of two semen extenders in terms of in vitro development of bovine embryos following IVF. Acta vet. scand. 1994, 35, 321-327. - In order to conform with current EC standards with regard to antibiotic cover, the Norwegian Cattle Association is currently investigating the use of Biladyl ${ }^{\circledR}$ as an alternative to the milk-based extender which has been traditionally used in Norway. A study was carried out to investigate the effect of using semen frozen with either milk extender or Biladyl ${ }^{\circledR}$ on the outcome of in vitro fertilization and embryo culture. Semen from 6 Norwegian Red bulls was used. There was a significant difference $p<0.05$ in terms of cleavage rate between the 2 extenders for 1 bull, $78.2 \%$ vs $94.9 \%$ for milk and Bilady ${ }^{\circledR}$ extenders, respectively, and for the overall total of $71.3 \%$ vs $76.1 \%$ for milk and Biladyl ${ }^{\circledR}$ extenders, respectively. There were no significant differences in terms of blastocyst yield amongst any of the bulls. In conclusion, the results suggest that Bilady $l^{\circledR}$ can be used as a replacement for the traditional milk-based extender without any adverse effects on blastocyst yields following in vitro fertilization.
\end{abstract}

Bilady ${ }^{\circledR}$; milk extender; AI; oocyte fertilization, culture.

\section{Introduction}

The 2 major functions of semen extenders are to preserve the fertility of sperm cells and to increase the total volume, so that the proper dose of spermatozoa for insemination can be conveniently packaged and used (Salisbury et al. 1978).

Microbial contamination of semen may effect spermatozoa directly, compete for substrate in semen extenders, and/or infect inseminated females. The result can be lowered conception rates and increased embryonic mortality or abortion, all of which are highly undesirable in an artificial insemination (AI) program. Even under the best conditions, some microbial contamination can occur. Both penicillin and streptomycin have been widely used since about 1950 , their popularity stemming from the overwhelming evidence of their beneficial effects on fertility (Salisbury et al. 1978).

Traditionally in Norway, semen has been frozen using a cheap-to-produce, milk-based extender containing penicillin/streptomycin as antibiotics. However, in order to conform with EC standards (Directive 92/387/EEC, Article 1, Annex 1A) it has become necessary to modify the semen extender used. Currently, the Norwegian Cattle Association is investigating the use of Biladyl ${ }^{\circledR}$ (Minitub, West 
Germany) as an alternative to the milk-based extender. Apart from conforming with EC standards with regard to antibiotic cover, the use of Biladyl ${ }^{\circledR}$ offers the advantage of improved working conditions for operators. All the pre-freezing steps can be carried out at room temperature, unlike the situation with milk extenders where following the first dilution the work must be carried out at $5^{\circ} \mathrm{C}$ in a cooling disc.

With this in mind, the objective of the present study was to compare the use of semen frozen using either a milk-based extender or Biladyl ${ }^{\circledR}$ on the in vitro developmental competence of bovine embryos produced by in vitro techniques. Field trials using semen from 45 bulls, including those used in the present study, frozen with the 2 extenders are being carried out parallel with the in vitro trials described here (Kommisrud et al. in prep.).

\section{Materials and methods}

\section{Oocyte collection and in vitro maturation (IVM)}

Ovaries from post-pubertal, non-stimulated heifers and cows were collected at local abattoirs and transported to the laboratory in thermos flasks containing sterile saline maintained at 35 to $37^{\circ} \mathrm{C}$. On return, ovaries were washed in fresh saline and immediately processed. Primary oocytes were recovered from 2 to $6 \mathrm{~mm}$ vesicular follicles by aspiration using an 18-gauge needle and a $5 \mathrm{ml}$ syringe.

For IVM, only those oocytes surrounded by a complete, unexpanded cumulus mass and exhibiting uniform cytoplasm were used. Selected oocytes were matured for $24 \mathrm{~h}$ in $2 \mathrm{ml}$ of maturation medium (50 oocytes per $2 \mathrm{ml}$ ) in $35 \mathrm{~mm}$ petri dishes. The maturation medium consisted of Tissue Culture Medium 199 (TCM 199, Sigma Chemical Company, St Louis, MO, cat. \# M-7528) supplemented with L-Glutamine (200 mM, Sigma, cat. \# G-7513)
$20 \%$ estrus cow serum (heat-treated at $56^{\circ} \mathrm{C}$ for $30 \mathrm{~min}$ ) and gentamycin (Gibco Life Technologies Inc., Gaithersburg, MD). Additional granulosa cells obtained by centrifugation and resuspension of cells after oocyte removal from follicular aspirates were added to the maturation dishes at a concentration of 3 to $5 \times 10^{6}$ cells $/ \mathrm{ml}$. The $\mathrm{pH}$ of the medium was adjusted to 7.4 , and all media were sterilized by filtration through a $0.22 \mu \mathrm{m}$ filter (Millipore, Bedford, MA) and equilibrated for at least $2 \mathrm{~h}$ prior to use. All cultures took place in an atmosphere of $5 \% \mathrm{CO}_{2}$ in air with maximum humidity at a temperature of $39^{\circ} \mathrm{C}$.

\section{Semen collection and processing}

Semen from 6 Norwegian Red Bulls of unknown fertility was used. As is standard procedure, in order to maximize semen production, 2 ejaculates were collected from each bull within $15 \mathrm{~min}$ of each other and subsequently pooled. The raw semen was divided into 2 equal volumes - one part subsequently diluted with milk extender, the other with $\mathrm{Bi}$ ladyl ${ }^{\circledR}$. The final composition of both extenders is shown in Table 1.

Procedures with milk extender. The first extender was added immediately after semen collection resulting in half of the final volume. This diluted semen was kept at $30^{\circ} \mathrm{C}$ for a minimum of $15 \mathrm{~min}$ to give the antibiotics sufficient time to function. The diluted semen was subsequently cooled at $5^{\circ} \mathrm{C}$ over a period of $30 \mathrm{~min}$. The second dilution was carried out in a cooling room. The semen was then equilibrated for $4 \mathrm{~h}$ during which time it was loaded into French mini straws (IMV, L'Aigle, France). These final stages were carried out in a cooling disc maintained at $5^{\circ} \mathrm{C}$. Procedures with Biladyl ${ }^{\circledR}$. As with the milk extender, the first extender was added immediately following semen collection resulting in half the final volume. This diluted 
semen was kept in a waterbath at $20^{\circ} \mathrm{C}$ for 20 min. The second dilution was carried out at room temperature as was the loading into French mini straws. The filled straws were cooled at $5^{\circ} \mathrm{C}$ over a period of $30 \mathrm{~min}$ following which the semen was equilibrated for $4 \mathrm{~h}$ at that temperature.

The subsequent freezing procedures were identical for both extenders. The straws were placed on ramps and loaded into the freezer (Digit Cool, IMV) at $5^{\circ} \mathrm{C}$. They were then cooled at a rate of $-4^{\circ} \mathrm{C} / \mathrm{min}$ down to $-10^{\circ} \mathrm{C}$. From there, they were cooled at a rate of $-40^{\circ} \mathrm{C} / \mathrm{min}$ down to $-150^{\circ} \mathrm{C}$. Subsequently they were plunged into liquid nitrogen at $-196^{\circ} \mathrm{C}$.

\section{In vitro fertilization}

Following culture for $24 \mathrm{~h}$, oocytes were denuded of their surrounding expanded cumulus cells by shaking them for several minutes in a $3 \%$ solution of tri-sodium citrate. Before transfer to the fertilization droplets they were washed by transfer through 3 successive dishes of washing medium (modified hepesbuffered Tyrode's solution, $\mathrm{pH}$ 7.4). They were randomly assigned to one of two groups to be inseminated with semen from the same ejaculate of a particular bull, which had been split and frozen using one or other of the 2 extenders.

A motile sample ( $>80 \%$ exhibiting progressive forward motion) of sperm for IVF was obtained by swim-up separation (Parrish et al. 1985). Briefly, approximately $0.25 \mathrm{ml}$ of frozen-thawed semen was layered under $1 \mathrm{ml}$ of capacitation medium (modified $\mathrm{Ca}^{++}$-free Tyrode's; $\mathrm{pH}$ 7.4) in conical tubes. Following incubation for $1 \mathrm{~h}$, the uppermost 0.5 to $0.8 \mathrm{ml}$ were removed and pooled in a conical centrifuge tube. This sample was then washed twice by centrifugation at $500 \mathrm{~g}$ for 7 to $10 \mathrm{~min}$. The resulting pellet was diluted with an equal vol-
Table 1. Final composition of skimmed milk and Biladyl® extenders.

\begin{tabular}{lcc}
\hline Constituent & \multicolumn{2}{c}{ Concentration (per 100ml) } \\
\cline { 2 - 3 } & Skimmed milk & Biladyl $^{\circledR}$ \\
\hline Skimmed Milk Powder & $9.2 \mathrm{~g}$ & - \\
Egg Yolk & $5.1 \mathrm{ml}$ & $20 \mathrm{ml}$ \\
Glycerol & $7 \mathrm{ml}$ & $7 \mathrm{ml}$ \\
Fructose & $2.1 \mathrm{~g}$ & $1.0 \mathrm{~g}$ \\
Tris & - & $2.42 \mathrm{~g}$ \\
Citric Acid & - & $1.38 \mathrm{~g}$ \\
Streptomycin & $50 \mathrm{mg}$ & - \\
Penicillin & $60,000 \mathrm{I} . \mathrm{E}$. & - \\
Tylosin & - & $5.25 \mathrm{mg}$ \\
Gentamycin & - & $26.25 \mathrm{mg}$ \\
Spectinomycin & - & $31.5 \mathrm{mg}$ \\
Lincomycin & - & $15.57 \mathrm{mg}$ \\
\hline
\end{tabular}

ume of capacitation medium containing 200 $\mu \mathrm{g}$ heparin/ml (Sigma, cat. \# H-3125). After incubation for $15 \mathrm{~min}$ the suspension was further diluted with capacitation medium to obtain the desired concentration of sperm.

Fertilization was carried out in $50 \mu \mathrm{l}$ droplets of modified Tyrode's medium (without glucose; pH 7.8) under mineral oil (Sigma, cat \# M-3516). The sperm motility stimulating mixture PHE (containing penicillamine, hypotaurine and epinephrine) was added at the time of insemination (Leibfried \& Bavister 1982). For IVF, $5 \mu \mathrm{l}$ of the final sperm suspension was added to each droplet containing 5 oocytes to give a final concentration of 1 to $1.5 \times 10^{6}$ spermatozoa $/ \mathrm{ml}$.

\section{In vitro culture}

Forty-eight $h$ post insemination (hpi), cleaved oocytes (2-8 cell stage) were transferred to a previously prepared granulosa cell monolayer (GCM; Jiang et al. 1990) for a further 5 to 7 days. Media was replenished every 48 to $72 \mathrm{~h}$. Results were based on cleavage rate (number of oocytes cleaved at $48 \mathrm{hpi} /$ total number inseminated) and blastocyst yield (number of 
blastocysts obtained as a percentage of the number of oocytes inseminated and as a percentage of the number of cleaved oocytes transferred to the GCM. Statistical comparisons were carried out using chi-square analysis.

\section{Results}

No differences in sperm motility post-thawing were noted between the 2 extenders (milk extender: $55.2 \% \pm 0.5$; Biladyl $56.9 \pm 0.4 ;$ mean \pm standard error; number of ejaculates $=81$ ). There was a significant difference $(\mathrm{p}<0.05)$ in terms of cleavage rate between the 2 extenders for one bull (4583: $78.2 \%, 43 / 55$ vs $94.9 \%$ $37 / 39$, for milk and Biladyl ${ }^{\circledR}$ extenders, respectively) and for the overall total $(71.3 \%$, $537 / 753$ vs $76.1 \%, 534 / 702$, for milk and Biladyl ${ }^{\circledR}$ extenders, respectively). There were no significant differences between the 2 extenders in terms of blastocyst yield among any of the bulls or for the overall total.

\section{Discussion}

The ultimate goal of semen preservation is to obtain pregnancies after artificial insemination as effectively as after natural mating. The concentration of spermatozoa in normal, freshly ejaculated bull semen is high, and considerable extension is necessary to provide a convenient volume to inseminate that will contain enough sperm cells to ensure maximum fertilization rates without wasting spermatozoa.

The most valid test of sperm fertilizing ability is to obtain viable pregnancies and normal offspring following in vivo insemination. While this procedure is not practicable in most mammals as a routine assay of sperm fertilizing ability, it is standard procedure for evaluating the fertility of bovine semen. A long standing goal of the AI industry has been to obtain a simple, accurate method for pre- dicting the fertility of bovine semen (Whitfield \& Parkinson 1992). In vitro fertilization technology may be such a method. The present study made use of IVF technology for the comparison of 2 different semen extenders with different antibiotic components in the freezing of semen for AI.

The question arises as to where the end-points of such a study should be fixed. This, of course, depends on the purpose of the study. If, as is the case here, the purpose is to investigate the influence of extenders on semen fertilizing ability post-thawing, one could argue that the cleavage rate would be sufficient as this, in theory, reflects the fertilization rate. However, it has been clearly shown by several authors (Eppig et al. 1990, Van de Sandt et al. 1990, Rose \& Bavister 1992) that differences occuring early on during in vitro development, even during in vitro maturation, can have a profound effect on events much further along the developmental axis (i.e. at the blastocyst stage) without these effects being evident at the time of first cleavage. As it would appear that using embryo yield following IVF as a parameter to predict bull fertility is the one nearest to that which currently evaluates bull fertility most accurately, i.e nonreturn rate (Marquant-Le Guienne et al. 1992), the end-point for the present study was fixed at the blastocyst stage. While a significant difference was observed between the 2 extenders in terms of cleavage rate for one bull and for the overall total, there were no significant differences in final blastocyst yield between the 2 treatments for any of the bulls or for the total, irrespective of whether the yield was calculated as a percentage of oocytes cleaved or oocytes inseminated. As no differences were apparent in blastocyst yield in vitro, it would seem that $\mathrm{Bi}$ ladyl ${ }^{\circledR}$ could be used instead of the traditional milk-based extender with the afore men- 
Table 2. Effect of semen extender on the outcome on in vitro fertilization.

\begin{tabular}{|c|c|c|c|c|c|c|c|}
\hline \multirow[t]{2}{*}{ Bull } & \multirow[t]{2}{*}{ Extender } & \multirow{2}{*}{$\begin{array}{c}\text { Oocytes } \\
\text { Inseminated }\end{array}$} & \multicolumn{2}{|c|}{ Cleaved } & \multicolumn{3}{|c|}{ Blastocysts } \\
\hline & & & No. & $\%$ & No. & $\% c$ & $\% d$ \\
\hline \multirow[t]{2}{*}{4594} & $\mathbf{M}$ & 100 & 84 & 84.0 & 14 & 16.7 & 14.0 \\
\hline & B & 140 & 126 & 90.0 & 23 & 18.2 & 18.2 \\
\hline \multirow[t]{2}{*}{4583} & M & 55 & 43 & $78.2^{\mathrm{a}}$ & 12 & 27.9 & 21.8 \\
\hline & B & 39 & 37 & $94.9^{b}$ & 15 & 40.5 & 38.5 \\
\hline \multirow[t]{2}{*}{4582} & $\mathbf{M}$ & 45 & 37 & 82.2 & 7 & 18.9 & 15.5 \\
\hline & B & 43 & 32 & 74.4 & 7 & 21.9 & 16.3 \\
\hline \multirow[t]{2}{*}{4578} & $\mathbf{M}$ & 266 & 193 & 72.6 & 20 & 10.4 & 7.5 \\
\hline & B & 159 & 120 & 75.5 & 14 & 8.8 & 8.8 \\
\hline \multirow[t]{2}{*}{4573} & $\mathbf{M}$ & 128 & 79 & 61.7 & 16 & 20.2 & 12.5 \\
\hline & B & 183 & 127 & 69.4 & 22 & 17.3 & 12.0 \\
\hline \multirow[t]{2}{*}{4552} & $\mathbf{M}$ & 159 & 101 & 63.5 & 21 & 20.8 & 13.2 \\
\hline & B & 138 & 92 & 66.7 & 15 & 16.3 & 10.9 \\
\hline \multirow[t]{2}{*}{ Total } & $\mathbf{M}$ & 753 & 537 & $71.3^{a}$ & 90 & 16.7 & 11.9 \\
\hline & B & 702 & 534 & $76.1^{b}$ & 96 & 18.0 & 13.7 \\
\hline
\end{tabular}

a,b Values in the same row pair with different superscripts differ significantly

c Blastocyst yield as a percentage of oocytes cleaved; $d$ as a percentage of oocytes inseminated

M: $\quad$ Skimmed Milk extender; B: Biladyl ${ }^{\circledR}$

Minimum of 3 replicates for each extender/bull

tioned advantages in terms of practicality and antibiotic composition.

While in vitro fertilization of zona-intact homologous eggs is the most informative in vitro test of sperm fertilizing ability available, it should be pointed out that there are still pronounced differences between IVF and in vivo fertilization, including sperm transport, conditions of sperm capacitation, and sperm:egg ratios at the site of fertilization. Indeed, it could be argued that using a swim up technique to discriminate between different semen treatments would reduce the chances of detecting differences due to sperm selection. However, Lathrop \& Foote (1986) used a swim up test to successfully predict bull fertility by layering extended semen in the bottom of a test tube and counting the number of spermatozoa which swam up a prescribed distance into an overlying TALP solution. It was found that the extender used significantly af- fected the number of sperm which swam up. In a subsequent field trial, the correlation coefficients between the nonreturn rate and the swim up results for fresh and frozen-thawed semen were greater than those observed between the \% motile spermatozoa and the nonreturn rate.

As a final comment, it is now well known that bulls differ in their ability to fertilize oocytes in vitro (Hillery et al. 1990, Marquant-Le Guienne et al. 1992, Shi et al. 1990, 1991) and even different ejaculates from the same bull may differ (Otoi et al. 1993). This is also apparent from the present study. However, it should be pointed out that the two extenders were compared within the bull on a given day, and not between bulls, caution should be taken in using the results to discriminate between the different bulls.

In conclusion, the results suggest that $\mathrm{Bi}$ ladyl $^{\circledR}$ can be used as a replacement for a 
milk-based extender without any adverse effects on blastocyst yield following fertilization in vitro. Also, the study illustrates one of the many potential applications of in vitro fertilization technology.

\section{Acknowledgement}

This work was supported by the Agricultural Research Council of Norway (Agricultural Biotechnology Program) and the Scandanavian Contact Agency for Agricultural Research. Thanks are also due to Dr. Wenche Farstad for help with the translation of the summary.

\section{References}

Eppig JJ, Schroeder AC, Van de Sandt JJM, Ziomek $C A$, Bavister BD: Developmental capacity of mouse oocytes that grow and mature in culture: the effect of modification of the protocol. Theriogenology 1990, 33, 89-100.

Hillery FL, Parrish JJ, First NL: Bull specific effect on fertilization and embryonic development in vitro. Theriogenology 1990, 33, 249 abstr.

Jiang $H S$, Wang WL, Lu KH, Gordon I: Effects of PMSG, insulin, osmolality and oestrous cow serum on development of IVF early bovine embryos cultured on granulosa cell monolayers. Theriogenology 1990; 33, 258.

Lathrop WF, Foote RF: The "swim up" test to predict fertility of bull spermatozoa. J Dairy Sci 1986, 69, (Suppl 1) 239.

Leibfried $M L$, Bavister BD: Effect of epinephrine and hypotaurine on in vitro fertilization in the Golden Hamster. J Reprod. Fertil. 1982, 66, 8793.

Lonergan $P$ : The application of in vitro fertilization techniques to the prediction of bull fertility. Reprod. Dom. Anim. 1994, 29, 12-21.

Marquant-Le Guienne B, Humblot P, Guillon N, Gerard $O$, Thibier $M$ : In vitro fertilization as a tool to evaluate fertility in the bovine. Proc 12th Int Cong Anim Reprod 1992, 2, 662-664.

Parrish JJ, Susko-Parrish JL, First NL: In vitro fertilization of bovine oocytes using heparin treated and swimup separated frozen-thawed bovine semen is repeatable and results in high frequencies of fertilization. Theriogenology 1985, 23, 216.

Rose TA, Bavister BD: Effect of oocyte maturation medium on in vitro development of in vitro ferti- lized bovine embryos. Mol. Reprod. Dev. 1992, 31, 72-77.

Salisbury GW, VanDemark NL, Lodge JR: Physiology of Reproduction and Artificial Insemination of Cattle. Second Edition. WH Freeman and Company, San Francisco, 1978.

Shi DS, Lu KH, Gordon I: Effects of bulls on fertilization of bovine oocytes and their subsequent development in vitro. Theriogenology 1990, 33, 324.

Shi DS, Lu KH, Gordon I, Polge C: Variation in cleavage and embryonic development of bovine oocytes in vitro fertilized with different bull ejaculates. Theriogenology 1991, 35, 271.

Otoi T, Tachikawa S, Kondo S, Suzuki T: Effects of different lots of semen from the same bull on in vitro development of bovine oocytes fertilized in vitro. Theriogenology 1993, 39, 713-718.

Van de Sandt JJM, Schroeder AC, Eppig JJ: Culture media for mouse oocyte maturation affect subsequent embryonic development. Mol Reprod Dev 1990, 25, 164-171.

Whitfield CH, Parkinson, TJ: Relationship between fertility of bovine semen and in vitro induction of acrosome reactions by heparin. Theriogenology 1992, 38, 11-20.

\section{Sammendrag}

Sammenligning av to fortynningsvaesker for saed når det gjelder in vitro utviling af bovine embryo etter IVF.

Avslaget for norsk rødt fe (NRF) ønsket å prøve ut Bilady ${ }^{\circledR}$ som frysefortynner ved frysing av oksesæd som et alternativ til den tradisjonelt brukte frysefortynner basert på skummet melk, slik at typen antibiotikatilsetning til frysefortynneren skulle være i overenstemmelse med gjeldende EU standard. Før en satte igang med omfattende og kostbare feltfors $\emptyset \mathrm{k}$, ønsket en derfor å unders $\varnothing \mathrm{ke}$, om det var noen forskjell på disse to frysefortynnerne ved in vitro fertilisering og embryo kultur fram til blastocyststadiet. Det ble benyttet frossen sæd fra 6 ulike okser i fors $\varnothing$ ket. Unders $\varnothing$ kelsen ble utført ved at hvert ejakulat ble delt i to, og halvdelene frosset med enten Biladyl ${ }^{\circledR}$ eller melkefortynner (split sample). Hos en okse viste det seg å være signifikant forskjell i delingsraten av egg etter befruktning in vitro med sæd fortynnet med henholdsvis melk og Biladyl ${ }^{\circledR}$ buffer $(78.2 \%$ mot $94.9 \%, \mathrm{p}<0.05)$. Det var også signifikant forskjell i delingsraten mellom split sample 
gruppene totalt for melk og Biladyl ${ }^{\circledR}$ fortynningsvæskene $(71.3 \%, 537 / 753$ og $76.1 \%, 534 / 702$, $\mathrm{p}<0.05)$. Imidlertid kunne det ikke påvises signifikant forskjell mellom fortynningsvæskene $\mathrm{i}$ andelen delte embryo som utviklet seg til blastocyster, verken hos individuelle okser eller totalt. Disse resultatene tyder på at en ikke risikerer dårligere fruktbarhetsresultater om en benytter Biladyl ${ }^{\circledR}$ istedet for melkefortynner ved frysing av oksesæd.

(Received May 10, 1994; accepted November 20, 1994).

Reprints may be requested from: P. Lonergan, INRA, Station de Physiologie de la Reproduction, 37380 Nouzilly, France. Fax: (33) 474277 43. E-mail: Lonergan@tours.inra.fr. 